\title{
ISLAMIC MODERATION AS A RESOLUTION OF DIFFERENT CONFLICTS OF RELIGION
}

\author{
Betria Zarpina Yanti ${ }^{1}$, Doli Witro ${ }^{2}$ \\ ${ }^{1}$ Institut Agama Islam Negeri Kerinci, Jambi \\ ${ }^{2}$ Institut Agama Islam Negeri Kerinci, Jambi \\ 1betriazarpinayanti001@gmail.com; 2doliwitro01@gmail.com
}

https://doi.org/10.36052/andragogi. v8i1.127

Diterima: 17 April 2020 | Disetujui: 15 Juni 2020 | Dipublikasikan: 30 Juni 2020

\begin{abstract}
Abstrak
Beberapa tragedi dan konflik kemanusiaan yang memilukan sekaligus mengkhawatirkan berlangsung silihberganti di berbagai Indonesia. Penyebab konflik tersebut dapat berupa faktor politik, kesenjangan ekonomi, kesenjangan budaya, sentimen etnis dan agama. Dengan demikian, menjadi sesuatu yang sangat urgen bagi kelompok-kelompok yang mudah terpapar konflik memahami moderasi Islam sebagai resolusi konflik perbedaan keyakinan beragama. Penelitian ini merupakan penelitian pustaka dengan metode penelitian kualitatif dan pendekatan deskriptif. Analisis data terhadap bahasan tersebut menggunakan pendekatan induktif dengan datadata bersumber dari buku-buku, jurnal, surat kabar, dan tulisan-tulisan ilmiah yang memiliki keterkaitan dengan obyek yang dikaji. Hasil penelitian menunjukkan bahwa problematika bangsa saat ini seperti kesenjangan ekonomi, kesenjangan budaya, sentimen etnis dan agama juga ancaman konflik hanya dapat diselesaikan melalui kerjasama dengan prinsip saling pengertian (mutual understanding) di antara umat beragama. Dengan demikian melalui moderasi Islam pluralitas, keragaman atau kemajemukan yang telah menjadi keniscayaan ini dapat dimanfaatkan sebagai energi sosial guna meretas problematika bangsa indonesia saat ini.
\end{abstract}

Kata Kunci: Moderasi Islam, Pluralitas, Resolusi, Konflik

\begin{abstract}
[ISLAMIC MODERATION AS A RESOLUTION OF DIFFERENT CONFLICTS OF RELIGION] Some tragedies and humanitarian conflicts that are both heartbreaking and worrying have been taking place in different parts of Indonesia. The cause of the conflict can be political factors, economic disparity, cultural disparity, ethnic and religious sentiments. Thus, it becomes very urgent for groups that are easily exposed to the conflict to understand Islamic moderation as a conflict resolution of differences in religious beliefs. This research is library research with qualitative research methods and descriptive approaches. Analysis of the data on the subject uses an inductive approach with data sourced from books, journals, newspapers, and scientific papers that are related to the object being studied. The results showed that the current national problems such as economic inequality, cultural disparity, ethnic and religious sentiments as well as the threat of conflict could only be resolved through cooperation with the principle of mutual understanding among religious communities. Thus through moderation of Islamic plurality, diversity, or diversity that has become a necessity can be utilized as universal energy to break down the problems of the Indonesian nation today.
\end{abstract}

Keywords: Islamic Moderation, Plurality, Resolution, Conflict 


\section{INTRODUCTION}

I slam and Muslims today face at least two challenges. First, the tendency of some Muslims to be extreme and strict in understanding religious laws and try to force this method in Muslim societies, even in some cases by using violence. Secondly, other tendencies which are also extreme by being loose in religion and subject to negative behaviours and thoughts originating from different cultures and civilizations (Hanafi, 2009).

In the past decade, several humanitarian tragedies that were both heartbreaking and worrying took place alternately in Indonesia (Burhanuddin \& Subhan, 2000); (Faiqah \& Pransiska, 2018). The series of social unrest has opened everyone's eyes about what is happening in this once peaceful country. According to Lewis Coser, it is stated that social conflicts which are in reality a part of a dynamic opportunity and are therefore positive. Lewis Coser does not deny that there are destructive conflicts and disintegrative functions. But he explained that there are positive social conflicts. Three arguments underlie his opinion. First, the conflict situation will increase the internal cohesion of the relevant groups; secondly, being able to create new associations and coalitions and thirdly, with the conflict building a balance of power between the groups involved (Coser, 1965). But the reality has turned into social unrest that is difficult to predict when it ends. In addition to the bombings I, II in Bali and Jakarta and other cities some time ago, the Ambon and Poso riots following the execution of Tibo CS have continued until now and have not yet shown signs of stopping. Not only is the escalation of conflict growing, the nature of the conflict develops not only horizontally, but also vertically.

Many people find it challenging to find the cause of all this. Complexity explains the cause of the conflict, which suddenly spread almost everywhere in the country, which was based on the inability to find the right formula for a conflict resolution-in accordance with the forms, types and escalation of conflicts that are indeed diverse, also varying causes. Causes of conflict can be in the form of political factors, economic inequality, cultural disparity, ethnic and religious sentiments. It's just that economic and political factors are often appointed to play the most dominant role compared to the two factors mentioned last. The emergence of cases of violence and terrorism in the name of religion is motivated by the phenomenon of narrow religious fanaticism as a result of the widespread movement of Islamic radicalism (Wiyani, 2013), for example burning and destroying places of worship, assault and killing of certain religious adherents. In Al-Quran Allah s.w.t. reminded mankind in Surah an-An'am verse 108:

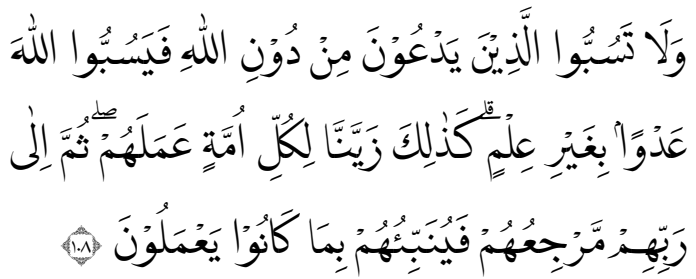

And do not insult those they invoke other than Allah, lest they insult Allah in enmity without knowledge. Thus We have made pleasing to every community their deeds. Then to their Lord is their return, and He will inform them about what they used to do (Departemen Agama Rl, 1989).

The above verse explains that if the faithful continue to berate and insult the unbelievers and revile their worship, it is feared there will be a commotion and conflict which will harm the believers themselves. It is from this problem that this verse is the reason for the prohibition of berating whatever is worshipped by unbelievers. But on another occasion, Allah s.w.t. also reiterates the importance of mutual respect in religion.

Nevertheless, there is nothing wrong for religious people to study and find effective ways for the comprehension, practice and spread of religious teachings in the midst of this pluralistic Indonesian society. There are several 
reasons why such activities are felt to be necessary. This is because of the narrow understanding of religion for its adherents, who potentially has the potential to ignite conflict. So it is natural that many secular scientists say that "religion is the source of riots" (Madjid, 1995). It seems that this kind of indication is excessive and tends to be judgmental. But one thing is sure, as often heard in the old thesis in the social sciences, that religion, besides being a unifying social factor, also has the opportunity to become an element of conflict. Therefore it becomes something very urgent for groups that are easily exposed to conflict in understanding Islamic moderation correctly and adequately. Islamic moderation is a view or attitude that always tries to take the middle position of two opposing and excessive attitudes so that one of the two perspectives meant does not dominate in one's mind and mood (Amin, 2014).

Related to this, Yusuf al-Qaradhawi stated that:

In the reality of real life, human beings cannot avoid different matters. Therefore al-Wasathiyyah Islamiyyah appreciates the elements of rabbaniyyah (divinity) and insaniyyah (humanity), combining maddiyyah (materialism) and ruhiyyah (spiritualism), combining revelation and reason, between maslahah ammah (aljamaaiyyah) and individual maslahah (alfardiyyah). As a consequence of the moderation of Islam as a religion, none of the elements of nature mentioned above is harmed (Al-Qaradhawi, 2011).

Based on the explanation above, there are significant and urgent matters to be studied more seriously, including addressing the dynamics of plurality in the life of the people and moderation of Islam as a conflict resolution of differences in religious beliefs. A correct understanding of all these issues will, in turn, be beneficial as one of the efforts to break the problem of relations between religious communities in Indonesia, which are often torn today. Based on this, the authors are interested in peeling it in this article.

\section{RESEARCH METHODS}

This research is pure literature research, in the sense that all sources of data come from written materials related to the topics discussed. The method used in this study is a qualitative research method with a descriptive approach (Sugiono, 2009).

Data analysis of the discussion uses the inductive approach, which is to draw general conclusions from specific conclusions (Bakry, 1981). During completing this research, the data used in the preparation of this paper were sourced from books, journals, newspapers, and scientific writings that have a relationship with the object being studied (Jalil, 2018).

\section{FINDINGS AND DISCUSSION}

\section{Findings}

\section{Responding to the Plurality Dynamics of Community Life}

Identical to the term pluralism, which means diverse, there are also various experts about this term. Pluralism means "plural, several, multiple things, or many. Therefore, something said to be plural must consist of many kinds of things, various perspectives and backgrounds" (Elmirzanah, 2002); (Mukzizatin, 2019). Thus, plurality is an expression to mention diversity, which in this article is intended as the dynamics of diversity in the lives of the people.

With regard to religious differences, observers of religious issues analyze that interreligious tensions are caused by the religions way of knowing that claims of truth and the idea of salvation. This situation is "exacerbated" by the teachings to save all mankind by embracing the religion that is believed to be accurate. In effect, certain people assume that he is right and-even- feel entitled and obliged to "straighten" people who disagree. At a more internal level, similar conditions also occur, such as the conflict between schools of thought and others. Because of the perspective of each religion, there is always the potential for friction between religions or followers of the same religion. In 
this case, religion is double-edged; religion has the power to make life peaceful, but it also has excellent potential to be the source of conflicts such as intolerance, radicalism, and even terrorism that shed human blood (Susanto, 2019).

The term pluralism itself is an old term which is getting more and more attention from everyone these days. The old term is put in place because the discussion about plurality has been further collaborated by philosophical thinkers in Greek conceptually with various alternatives to solve it. The Indonesian nation itself is a nation that is often referred to as the most diverse nation in the world. Indonesia is also known as a predominantly Muslim country (Witro, 2020a), but Indonesia also recognizes other religions according to those mentioned in the Law. In a country with a population of more than 270 million people (Yusuf et al., 2020), there are no less than 300 ethnic groups with their respective cultural identities, more than 250 languages spoken, diverse customs and diverse religions which is in accordance with the slogan Bhinneka Tunggal Ika (Purwaningsih \& Witro, 2020). Thus, life goes on as it is for years. People with different tribes can live in harmony with other tribes of different traditions, languages, religions and beliefs. Friction and conflict often occur because it is part of the dynamics of society, but all the friction is still in the controlled stage. The situation changes when a community is unable to respond to and manage all existing differences and conflicts into social energy for the fulfilment of common interests.

The conflict itself is a necessity. Its existence always accompanies the plural society. It is almost impossible for a plural society to be involved and conflicted. The conflict here is indeed not synonymous with riots and disputes. Conflicts may not surface because they are muted. If circumstances allow hidden conflict, it will explode as it is today. In other words, as a result of the disbanding of disproportionate conflicts, a battle that is constructive and potentially disintegrative will be born for the survival of a nation.

If pluralism is given, while conflict is something internal in it, so that raises questions about how to manage plurality and existing conflicts so that it becomes social energy for the creation of a better national order, of course, the answer is long by involving the assessment of all the factors that exist. However, related to this study (understanding plurality), it turns out that maintaining harmony is not enough just to understand the diversity that is around apathetically and passively-understanding pluralism even though it involves pluralistic selfattitude. An attitude of empathy, honesty and fairness puts diversity, the difference in its place, namely by respecting, understanding and acknowledging the existence of others, as well as respecting and recognizing one's own existence.

Likewise, in responding to religious pluralism. The attitude that someone should do is to understand and judge other religions based on their own standards and provide opportunities for them to articulate their beliefs freely. Alwi Shihab gives a pretty good picture in articulating religious pluralism. According to him, religious pluralism is that each adherent of religion is required to not only recognize the existence and rights of others but also engage in efforts to understand differences and similarities, to achieve harmony in diversity (Shihab, 1997). Through an understanding of true pluralism, followed by efforts to create a peaceful life like this, it will create tolerance among religious people in Indonesia.

Tolerance in question is, of course, not negative tolerance, but true tolerance is positive tolerance. The first tolerant attitude is a false tolerance and full of pretence. This first kind of tolerance encourages one not to accentuate his religion in front of people of other faiths. If Christians, then don't accentuate their Christianity before Muslims, and vice versa. While the second tolerance is real tolerance, which invites every religious community to honestly acknowledge and 
express their diversity without being covered up, thus, the identity of each religious community is not eliminated, even each religion can freely develop it. This is a tolerance that was once recommended by Kuntowijoyo (Effendi, 2002).

Although the concept of positive tolerance as above is somewhat old, its implementation is not an easy matter. A recent survey conducted by the Center for Islamic and Community Studies (PPIM) of UIN Jakarta on the Attitudes of the Islamic Educating Community and Tolerance and Pluralism shows some quite alarming figures. A survey conducted in early 2016 generally showed that the Indonesian Islamic education community showed a lack of even intolerant attitude. This can be seen from a large number of respondents (85.7\%) who do not agree with family members marrying nonMuslims, family members may marry nonMuslims, as long as they convert to Islam first $(88 \%)$. As for the question; compared to other people, Muslims are the best as much as $92.5 \%$ of the people. Therefore, non-Muslims must convert to Islam (58.7\%). No greetings and greetings and merry christmas to non-Muslims (73.5\%) and every Muslim is obliged to preach their religion to non-Muslims (73\%) (Buletin Islam \& Good Governance, 2006). The existence of facts like this is certainly something that is very alarming because this happens in the Islamic education community. This means that if the population of education as part of the transmission of Islamic teachings shows this attitude, then you can imagine what about the lay community. This is the challenge of the government and other stakeholders in overcoming conflicts in the Unitary Republic of Indonesia.

\section{Discussion}

\section{Moderation of Islam as a Conflict Resolution on Difference in Religious Belief}

The moderation of Islam in Arabic is called al-Wasathiyyah al-Islamiyyah. Al-Qaradawi mentions several vocabularies that are similar in meaning to those including the words Tawazun,
I'tidal, Ta'adul and Istiqamah. While in English as Islamic Moderation (Amin, 2014).

The terminology of Islamic moderation is the terminology of the many terms that are often used to refer to the labels of Muslims such as modernist, progressive and reformist Islam. As El Fadl acknowledges, this moderate terminology is considered the most appropriate among the other language. Although moderates are also often described as modernist, progressive and reformist groups, none of these terms replaces the moderate word. This is based on the legitimacy of the Al-Quran and the Hadith of the Prophet that Muslims are ordered to be moderate. This is where the moderate term finds its roots in the Islamic tradition (ElFadl, 2005). Moreover, the terminology wasathiyyah is an identity (Hasan, 2016) and wasathiyyah is the primary character of Islam (Bagir, 2017). The concept of wasathiyyah in some Islamic literature was interpreted variously by experts. According to al-Salabi, the word wasathiyyah means:

First, from the root word wasth in the form of dharaf, which means baina (intermediate). Second, from the root of the word wasatha which contains many meanings, including: 1) in the form of isim (noun) which contains the understanding between the two ends; 2 ) in the form of a meaningful characteristic (khiyar) selected, especially, the best; 3) wasath which means al-'adl or just; 4) wasath can also mean something that is between the good (jayyid) and the bad (radi') (AlSalabi, 2011).

Moderation in the general sense of our time means balance in beliefs, attitudes, behaviour, order, muamalah and morality. This means that Islam is a very moderate religion, not excessive in all cases, not excessive in religion, not extreme in beliefs, not arrogant or gentle and others (Amin, 2014).

Islamic moderation is a view or attitude that always tries to take the middle position of two opposing and excessive attitudes so that one of the two perspectives meant does not 
dominate in one's mind and mood. In other words, a moderate Muslim is a Muslim who gives each value or aspect opposite a specific portion not more than the proper proportion ( $\underline{\mathrm{Al}-}$ Qaradhawi, 2011).

The opposite of wasathiyyah is tatarruf which shows the meaning of the tendency towards the periphery, extremism, radicalism and overdoing it (Kamali, 2015) whereas alQaradhawi identifies wasathiyyah into a number of broader definitions, such as fairness, istiqamah, elected and best, security, strength, and unity (Al-Qaradhawi, 2011).

Apart from the various meanings above, Hilmy identified several characteristics of the use of the concept of moderation in the context of Indonesian Islam, including:

1) Ideology without violence in spreading Islamic teachings; 2) Adopt a modern way of life with all its derivatives, including science and technology, democracy, human rights and the like; 3) The use of rational thinking; 4) Contextual approach in understanding Islam, and; 5) Use of ijtihad (intellectual work to make legal opinions if there is no explicit justification from the Al-Quran and Hadith). Five characteristics can be extended to other characteristics such as tolerance, harmony and cooperation between religious groups (Hilmy, 2013).

Some of the wasathiyyah meanings above show that this terminology is very dynamic and contextual. This terminology also not only stands on one aspect but also involves a balance between mind and revelation, material and spirit, rights and obligations, individualism and collectivism, texts (Al-Quran and Hadith) and personal interpretation (ijtihad), ideal and reality, permanent and temporary, all of which are integrated (Al-Qaradhawi, 2000). That is why Hanapi called wasathiyyah a comprehensive and integrated approach. This concept asks Muslims to practice Islam in a balanced and complete way in all aspects of community life by focusing on improving the quality of human life related to the development of knowledge, human development, legal systems, economic and financial systems, political systems, education systems, nationalities, defence, unity, racial equality and others (Mohd Shukri Hanafi, 2014); (Khoiri, 2019). No wonder the ummah wasath is a model that will be witnessed before other people.

Limitation of wasathiyyah understanding of the conception of Islam in the context of maintaining the unity of the people departs from the fact that this concept is pure and original, a concept that comes from Islam with all its contents as confirmed by al-Qaradhawi. However, if this concept is matched with the concept of moderation that develops in general, then in the context, there are at least two terms that must be distinguished, so as not to confuse Islam itself, namely moderate Islam and Islamic moderation.

For the first term (moderate Islam), this term was never known in Islam, because Islam as a religion that has been perfect, complete and one (see Q.S. al-Maidah verse 3, Q.S. alAnbiya' verse 92 , and Q.S. al- Mu'minun verse 52 ), does not recognize any categorization in its nature. Is that categorization that is considered negative, such as radical Islam, fundamentalist Islam, militant Islam, Jihadist Islam, and others. Nor is categorization considered positive, such as progressive Islam, moderate Islam, modernist Islam, and others.

As for the second terminology (Islamic moderation), Muslims throughout all times have agreed that moderation as the equivalent of the word wasathiyyah which is one of the characteristics and ways of thinking that have been inherent in Islam itself, which refers from authoritative sources while the extremist attitudes that occur within Muslims are part of the deviations that must be corrected. As happened in the Khawarij sect during the best friend of the Prophet. As well as the Qadariyyah and Jabariyyah sects in subsequent periods. Therefore, it is essential to pay attention to the 
problem of using language and basic terms in Islam.

Naquib al-Attas, a Malaysian Muslim scholar, born in Indonesia, warns of the need to use language or basic terms correctly in Islam so that there is no widespread error and error in understanding Islam and his views on nature and truth. According to Naquib al-Attas, many key terms in Islam that have now become obscured are used arbitrarily so that they deviate from their true meaning. One example is the misuse of the meaning of the term adab, which is interpreted only as customary rules regarding decency, which are usually the practice of pretending to be polite (Al-Attas, 2007; Husaini, 2009).

Besides, Islam must also be distinguished as a religion and teachings, with its adherents. As a religion and teachings, Islam has never changed. Islam is complete and perfect. It's just that the understanding of its adherents to Islam is different, which one is complete and not complete, and some understand Islam from one aspect, while the other aspects are abandoned. For example, Islam is only understood with tasamuh (tolerance), while other Islamic teachings, which forbid tasamuh from being used. From here, it is as if Islam only teaches tasamuh so that Islam seems permissive. When in fact some may be tasamuh and some who are not. So, it must be divided between Islam and the person.

The application of this tasamuh must be based on a sincere attitude in accepting the attitude of others, but by still holding the principles that exist in yourself without compromising these principles. Tasamuh will be seen to be applied in life, if the differences that are owned between communities go well without one of them sacrificing the principle he has. In other words, tasamuh only applies to the technical aspects and detailed aspects, not to the principal matters. Al-Quran has explained the character of Islam, which later gave birth to tasamuh that can support the ethics of differences that occur in society (Yanti \& Witro, 2019).
Apart from that, some consider that the concept of wasathiyyah is not an attitude taken by someone towards their religion, nor is it a method for understanding religion. However, wasathiyyah is a character acquired by a Muslim as a result of his commitment to religious teachings. It is this character that makes him into the group syuhada' 'ala an-nas (witnesses over humans), that is, witnesses received by God for his testimony.

Also, this character has been described in the religious attitude of the Prophet Muhammad s.a.w. and His friends. Because with the wisdom of Allah the Most Wide, God has given examples of real life in the form of congregation or community that manifested in this wasathiyyah. Allah s.w.t. and Prophet Muhammad s.a.w. have been witnesses to the companions of the Prophet Muhammad s.a.w. that they have manifested the character of the wasathiyyah.

Therefore, everyone who is close to manhaj the community of friends in understanding and practicing religious teachings and enthusiastically following in his footsteps, he is getting closer to wasathiyyah (Al-Luwaihiq, 2003; Ansory, 2014). Although these two views are essentially reinforcing one another. In the sense that if a Muslim with high commitment and consistently implement the sharia rules with the right understanding, then the characteristics of this wasathiyyah will appear in him, then gave birth to a proportional attitude in assessing and responding to everything.

Various real images on the ground show that weaving a cord of harmony and tolerance in the midst of religious plurality is indeed not an easy matter. Several factors are a threat to the achievement of tolerance, namely:

First, the aggressive attitude of religious adherents in preaching their religion. Secondly, there are religious organizations which tend to be oriented towards increasing the number of members in a quantitative manner rather than making improvements in the quality of the faith of 
their constituents. Third, the economic disparity between adherents of different religions. In order to minimize threats like this (especially the first and second threats), then inevitably Muslims, as well as other people, are required to organize the spread or propaganda activities of religion in a more proportionate and immoral way (Ismail, 2015).

This maturity needs to get the attention of all parties because efforts to foster religious harmony are often constrained by the fact that the socialization of religious teachings at the grassroots level is dominated by preachers who are less sensitive to religious harmony. The high spirit of da'wah from the activists of this da'wah is often tainted byways of denigrating the religion of others.

Related to this, some of the following things seem to be a fundamental problem that must always be sought if Islam is expected to be a rahmah for all nature. These three things are 1) Preparation of wise lecturers who are inclusive, not exclusive; 2) Selecting soothing propaganda material and 3) Transformative paradigm propaganda as capital towards cooperation among religious communities. First, it is closely related to the preparation of the personal competence of a preacher while the remaining supporting competencies must be the concern of a preacher or muballigh.

It is the duty of every Muslim not only to carry out the teachings of his religion but also preach it to oneself and others wherever and whenever. Da'wah as an effort to spread the teachings of Islam is a sacred mission as a form of faith of every Muslim in the truth of their religion. The Al-Quran expressly mentions Surah an-Nahl verse 125:

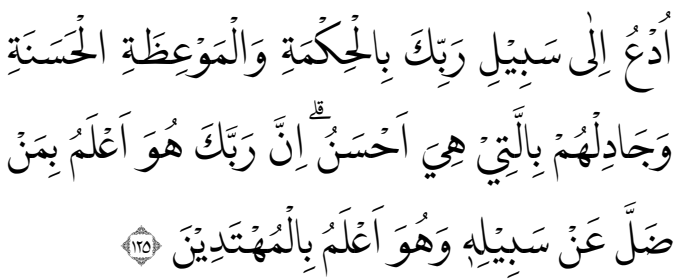

Invite to the way of your Lord with wisdom and good instruction, and argue with them in a way that is best. Indeed, your Lord is most knowing of who has strayed from His way, and He is most knowing of who is (rightly) guided (Departemen Agama RI, 1989).

Likewise, a Hadith that is often heard explicitly calls for the delivery of the truth from the prophet even though one verse (a little) and several other propositions that are compatible with the advice of preaching.

From the argument above, one thing that is certain and must be underlined is that preaching should be done wisely and full of maturity. Maturity as a people who will deliver the nobility of Islam in the eyes of other groups and make others feel safe and not threatened with Islam. In order to achieve such a noble goal, then the following things should be done by the government and supported by people in fostering a pluralistic life.

First, it provides awareness of the heterogeneity of the target da'wah community. The diversity of the audience (the target of da'wah) demands different methods and materials as well as the da'wah strategies according to their needs. The Prophet himself through his Hadith, encourages people to give advice, information to others according to their level of understanding.

Second, the government directs that religious activities be carried out by denying hateful elements, such as hate speech and hoax, which is carried out verbally or through social media (Witro, 2018, 2019, 2020b). The essence of religious activity must involve meaningful dialogue full of wisdom, attention, patience, and compassion. Only in this way, the audience will accept the invitation of religious teachings with full awareness.

Third, each religious community conducts persuasive religious activities, far from coercive attitudes, because such attitudes aside from lack of wisdom, will also result in the reluctance of people to follow the call of religious teachings, which in turn will make the sacred mission of the cry of religion fail. This is as the word of God in Surah al-Kahfi verse 29: 


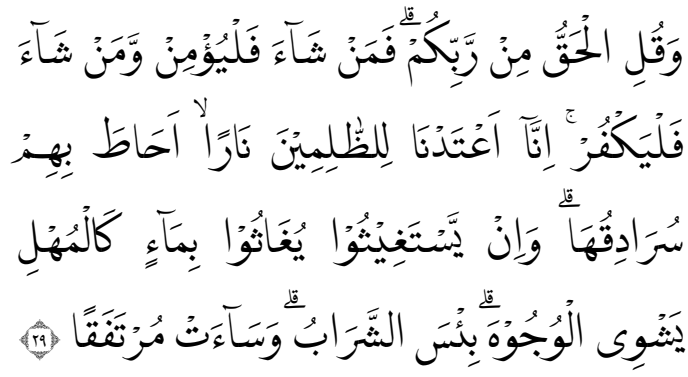

And say, "The truth is from your Lord, so whoever wills-let him believe; and whoever wills-let him disbelieve". Indeed, We have prepared for the wrongdoers a fire whose walls will surround them. And if they call for relief, they will be relieved with water like murky oil, which scalds (their) faces. Wretched is the drink, and evil is the resting place (Departemen Agama $\mathrm{Rl}_{\text {, }}$ 1989).

In Surah al-Baqarah verse 256, Allah s.w.t. also said:

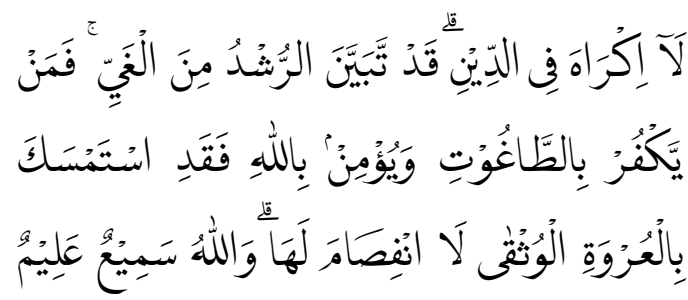

There shall be no compulsion in (acceptance of) the religion. The right course has become clear from the wrong. So whoever disbelieves in Taghut and believes in Allah has grasped the most trustworthy handhold with no break in it. And Allah is Hearing and Knowing (Departemen Agama Rl, 1989).

Fourth, the government needs to direct lecturers to avoid thoughts and attitudes that insult and denigrate other religions and blaspheme God, who is a belief in other religious communities.

Fifth, the government and related stakeholders need to mediate differences and avoid extremism in religion. The principle of Islam in religion is a middle ground, moderate attitude (umatan wasathan). Shihab further stated that in order to prevent extremism and maintain balance and tolerance in religion is to streamline preaching internally within Muslims, so that when Muslims can do so, then others will be appreciative of Islamic ideals such as tasamuh (tolerance), i'tidal (moderation) and adl (justice) (Shihab, 1997).

The things above and of course, coupled with personal competence that must be possessed by a religious preacher, if carried out seriously it will be very useful for efforts to maintain harmony among all religious adherents. Invitations to find common ground among followers of religions other than Islam often referred to as ahlu al-kitab, have further implications in the form of the belief that anyone can obtain salvation as long as he believes in Allah, in the Day of Judgment and doing good. The concept of ahlu al-kitab in Islam actually designates all religious groups outside of Islam which are not only limited to Judaism and Christianity, including the Majus and Shabi'in which are explicitly recognized by the Al-Quran as a misleading belief (see alBaqarah verse 62 and al-Hajj verse 17). Many scholars claim that the concept of ahlu al-kitab refers to all religions, including Buddhism, Hinduism, Confucianism. It was Rasyid Ridho who firmly confirmed this with his statement which appeared to be that the Al-Quran mentions adherents of previous religions, Sabi'in and Majusi and does not mention Brahmas (Hindus), Buddhists and Confucian followers because (only) the Sabians and Magi who were known by the Arabs were the first targets of the Al-Quran, because the Musiques and Shabi'ins were close to them in Iraq and Bahrain, and they (the Arabs) had not yet travelled to India, Japan and China, so they know the other groups (Madjid, 2004). The same thing is also recognized by Fazlur Rahman, according to Rahman, the word ahlu al-kitab is often used in the Al-Quran not to refer to a unique book revealed, but rather as a generic term that indicates the totality of God's revelation (Rahman, 1980). Because for all of them, Allah has provided each reward, there is no concern for them and no sadness. 
Starting from the view of the Al-Quran, which is unique about pluralism, actually, humans can draw ibrah that understanding pluralism is not enough by saying that a pluralistic, diverse, different ethnic groups and religions, which actually seems to imply the existence of fragmentation, not pluralism. Pluralism must be understood as "the true relationship of diversity in the bonds of civility (genuine engagement of diversity within the bounds of civility)". In short, pluralism cannot be understood merely as a negative good where pluralism is only used to eliminate fanaticism (ta'ashu-biyah) (Rachman, 2004).

\section{CONCLUSION}

In accordance with the principle that Islam is a mercy for all of nature, empowerment and improvement of the quality of life as recommended by the Al-Quran should be enjoyed by all living creatures regardless of differences in beliefs and religions. Therefore, with a correct understanding of Islamic moderation, the Islamic da'wah model will be more meaningful if it is carried out by involving cooperation with all parties.

Many things can be done, and many problems are resolved through collaboration between religious communities. The challenges of humanity in the modern era such as poverty and the danger of hunger caused mainly by injustice, economic exploitation, social, political and racial injustice, gender as well as the threat of conflict and damage to ecosystems can only be resolved through cooperation with the principle of mutual understanding among religious communities. Thus through moderation of Islamic plurality, diversity or diversity that has become a necessity can be used as social energy to break the problems of mankind. 


\section{REFERENCES}

Al-Attas, S. N. (2007). Tinjauan Peri Ilmu dan Pandangan Alam. Pulau Pinang: Universiti Sains Malaysia.

Al-Luwaihiq, A. bin M. (2003). Ghuluw Benalu dalam ber-Islam. Tebing Tinggi: Darul Falah.

Al-Qaradhawi, Y. (2000). Thaqafatuna Bayna al-Infitah wa al-Inghilaq. Kairo: Dar al-Shuruq.

Al-Qaradhawi, Y. (2011). Kalimat fi al-Wasathiyyah wa Madlimiha. Kairo: Dar al-Syuruq.

Al-Salabi, A. M. M. (2011). Al-Wasathiyyah fi al-Qur'an al-Karim. Kairo: Maktabah at-Tabiînn.

Amin, R. (2014). Prinsip Dan Fenomena Moderasi Islam Dalam Tradisihukum Islam. Al-Qalam, 20(3), 23. https://doi.org/10.31969/alq.v20i3.339

Ansory, I. (2014). Wasathiyyah/Moderasi Islam. Retrieved May 7, 2020, from Rumah Fiqih Indonesia website: https://www.rumahfiqih.com/

Bagir, H. (2017). Islam Tuhan Islam Manusia: Agama dan Spiritualitas di Zaman Kacau. Bandung: Mizan.

Bakry, H. (1981). Sistematik Filsafat. Jakarta: Widjaya.

Buletin Islam \& Good Governance. (2006). Kekerasan Keagamaan di Kalangan Muslim: Mempertimbangkan Faktor Pendidikkan.

Burhanuddin, J., \& Subhan, A. (2000). Sistem Siaga Dini Terhadap Kerusuhan Sosial. Jakarta: Balitbang Agama Depag RI and PPIM.

Coser, L. (1965). The Function of Social Conflict. New York: Free Press.

Departemen Agama RI. (1989). Al-Quran dan Terjemahnya. Semarang: CV Toha Putra.

Effendi, B. (2002). "Menyoal Pluralisme di Indonesia" dalam Living Together in Plural Societies; Pengalaman Indonesia Inggeris (R. J. Antoni, Ed.). Yogyakarta: Pustaka Pelajar.

El-Fadl, K. A. (2005). Selamatkan Islam dari Muslim Puritan, (Penerjemah) Helmi Mustofa. Jakarta: Serambi.

Elmirzanah, S. et al. (2002). Pluralisme, Konflik dan Perdamaian: Studi Bersama Antar Iman. Yogyakarta: Pustaka Pelajar.

Faiqah, N., \& Pransiska, T. (2018). Radikalisme Islam Vs Moderasi Islam: Upaya Membangun Wajah Islam Indonesia Yang Damai. Al-Fikra : Jurnal IImiah Keislaman, 17(1), 33. https://doi.org/10.24014/af.v17i1.5212

Hanafi, M. M. (2009). Konsep Al-Wasathiyyah dalam Islam. Harmoni: Jurnal Multikultural \& Multireligius, VIII(32), 36-52.

Hasan, M. T. (2016). Pendidikan Multikultural Sebagai Opsi Penanggulangan Radikalisme. Malang: Lembaga Penerbitan UNISMA.

Hilmy, M. (2013). Whither Indonesia's islamic moderatism?: A reexamination on the moderate vision of Muhammadiyah and NU. Journal of Indonesian Islam, 7(1), 24-48. https://doi.org/10.15642/JIIS.2013.7.1.24-48

Husaini, A. (2009). Pancasila Bukan untuk Menindas Hak Konstitusional Umat Islam, Kesalahpahaman dan Penyalahpahaman Terhadap Pancasila 1945-2009. Jakarta: Gema Insani Press.

Ismail, F. (2015). Dinamika Kerukunan Antarumat Beragama. Bandung: Remaja Rosdakarya.

Jalil, A. (2018). Pernikahan Beda Agama dalam Perspektif Hukum Islam dan Hukum Positif di Indonesia. Andragogi: Jurnal Diklat Teknis Pendidikan Dan Keagamaan, 6(2), 46-69. https://doi.org/10.36052/andragogi.v6i2.56

Kamali, M. H. (2015). The Middle Path of Moderation in Islam: The Qur'anic Principle of Wasathiyyah. New York: Oxford University Press.

Khoiri, A. (2019). Moderasi Islam Dan Akulturasi Budaya; Revitalisasi Kemajuan Peradaban Islam Nusantara. Islamdina, 20(1), 1-17.

Madjid, N. (1995). Islam Agama Kemanusiaan: Membangun Tradisi dan Visi Baru Islam di Indonesia. Jakarta: 


\section{Paramadina.}

Madjid, N. et al. (2004). Fiqih Lintas Agama: Membangun Masyarakat Inklusif Pluralis. Jakarta: Paramadina.

Mohd Shukri Hanafi. (2014). The Wasatiyyah (Moderation) Concept in Islamic Epistemology: A Case Study of its Implementation in Malaysia. International Journal of Humanities and Social Science, 4(9(1)), 51-62.

Mukzizatin, S. (2019). Relasi Harmonis Antar Umat Beragama dalam Al-Qur'an. Andragogi: Jurnal Diklat Teknis Pendidikan Dan Keagamaan, 7(1), 161-179.

Purwaningsih, R. F., \& Witro, D. (2020). Islam Nusantara in Slogan Bhinneka Tunggal Ika: Al-Quran Perspective. Cakrawala, 15(1), 1-10. https://doi.org/https://doi.org/10.31603/cakrawala.v15i1.3301

Rachman, B. M. (2004). Islam Pluralis: Wacana Kesetaraan Kaum Beriman. Srigunting.

Rahman, F. (1980). Major Themes of The Qur'an. Chicago: Bibliotheca Islamica.

Shihab, A. (1997). Islam Inklusif: Menuju Sikap Terbuka dalam Beragama. Jakarta: Mizan.

Sugiono. (2009). Metode Penelitian Kuantitatif dan Kualitatif. Bandung: Alfabeta.

Susanto, A. (2019). Peran Kepala KUA dalam Membangun Moderasi Beragama di Kabupaten Majalengka. Andragogi: Jurnal Diklat Teknis Pendidikan Dan Keagamaan, 7(2), 232-245. https://doi.org/10.36052/andragogi.v7i2.92

Witro, D. (2018). Problematika Hoax di Media Sosial: Telaah Pesan Tabayyun dalam Surat al-Hujurat/49: 6. Proceedings of the 3rd BUAF (Borneo Undergraduate Academic Forum), 183-190. Kalimantan Tengah, Indonesia, 17-19 0ktober: Institut Agama Islam Negeri (IAIN) Palangkaraya.

Witro, D. (2019). Peaceful Campaign In Election Al-Hujurat Verse 11 Perspective. Alfuad:Jurnal IImu Sosial Keagamaan, 3(2), 15-24. https://doi.org/http://dx.doi.org/10.31958/jsk.v3i2.1796

Witro, D. (2020a). Ulama and Umara in Government of Indonesia: a Review Relations of Religion and State. Addin, $14(1)$.

Witro, D. (2020b). Urgency Rijalul Posting In Preventing Hoax: Quranic Perspective. Is/amic Communication Journal, 5(1), 38-49. https://doi.org/http://dx.doi.org/10.21580/icj.2020.5.1.5451

Wiyani, N. A. (2013). Pendidikan agama Islam berbasis anti terorisme di SMA. Jurnal Pendidikan Islam, 2(1), 6583. https://doi.org/10.14421/jpi.2013.21.65-83

Yanti, B. Z., \& Witro, D. (2019). Self Maturity and Tasamuh As a Resolution of Religious Conflicts. Intizar, 25(2), 87-94. https://doi.org/https://doi.org/10.19109/intizar.v25i2.5608

Yusuf, M., Witro, D., Diana, R., Santosa, T. A., Alfikri, A. 'Alwiyah, \& Jalwis. (2020). Digital Parenting to Children Using The Internet. Pedagogik Journal of Islamic Elementary School, 3(1), 1-14. https://doi.org/10.24256/pijies.v3i1.1277 